\title{
Metacognitive Instruction and Students' Achievement in Solving Mathematical Word Problems
}

\author{
Afia Iqbal ${ }^{*}$ \\ Naveed Sultana $^{* *}$ \\ Muhammad Tanveer Afzal ${ }^{* * *}$
}

\begin{abstract}
Mathematics is considered as an important subject of elementary curriculum throughout the world due to its use in different fields of life. The compulsory component of mathematics is mathematical word problems. Word problems are considered as the difficult part of mathematics not only by students but mathematics teachers as well. Special teaching strategies are required to teach mathematical word problems to cope with the recent educational standards. Metacognitive instruction for teaching word problems has been proved affective by different educationists and researchers of world. Metacognitive instruction uses the hypothetical definition of metacognition, metacognitive knowledge and metacognitive skills and practicing of self addressed questions. Students are practiced to ask a series of self addressed questions while solving word problems about: understanding, connection, strategies, and reflection. The present study was an attempt to experiment metacognitive instruction for teaching mathematical word problems on sixth class students at Govt. High School Abbottabad and to check its effectiveness as compared to traditional method of teaching. The study used true experimental research design; specifically the pretest-posttest control group design with 80 subjects $(40+40)$ and data was collected and analyzed by t-test and descriptive analysis. The finding of study proved metacognitive instruction as an effective method for teaching mathematical word problems at elementary level.
\end{abstract}

* PhD Scholar at Department of Secondary Teacher education, Allama Iqbal Open University, Islamabad. Email:afiaiqbal55@gmail.com

** Associate Professor, Department of Secondary Teacher Education, Allama Iqbal Open University, Islamabad.

*** Assistant Professor, Department of Secondary Teacher Education, Allama Iqbal Open University, Islamabad. 
Keywords: Metacognitive Instruction, Mathematical Word Problems, Traditional Method, Experimental Research

\section{Introduction}

Mathematics being the doorway of science and technology is the basic component of curriculum taught at elementary and secondary level throughout the world. A solid understanding of mathematical knowledge and concepts is the requirement of today's fast moving society that is entirely dependent on technology. The most challenging and difficult aspect of mathematics is solution of mathematical word problems. Students hesitate to solve them and show poor performance while solving word problems. Like textbooks, state assessment also demands students to solve word problems (Xin, 2007). The major factor of the underachievement in mathematics is word problem understanding and solving strategy (Salma, \& Sherwin 2012). Educationists and researchers have always shown a lot of concern toward word problems.

Diverse teaching techniques and strategies are required to employ by mathematics teachers in classrooms to deal with the varied nature of the mathematical knowledge. Teachers have been using different teaching strategies to teach word problems. Teachers, especially in Pakistan are following Chalk and Board method known as the traditional teaching method. Teacher is the main source of knowledge in this method. Teacher reads the statement of problem and then solves it on board and students copy it on their notebooks. Students neither try to understand the word problem nor connect it to prior knowledge to solve it. There are few teachers who attempt to improve student's thinking process. Effective instruction helps students to understand and comprehend the problem, become aware of the strategies used to solve the problems, connecting it with previous knowledge and to reflect on the solution and the processes.

One of the effective teaching strategies, Metacognitive instruction has been used to solve mathematical word problems in different countries of the word. It confirms the accomplishment of main aim of learning unlike traditional method of teaching. Different researches and studies have confirmed a positive relationship between metacognitive instruction and student's achievement, and it has been established that students taught through metacognitive instruction showed better performance as compared to students who were not taught through metacognitive instruction in different school domains (Maqsud, 1997 \& 
Fazal, 2010). Similarly Helms-Lorenz \& Jacobse, (2008), acknowledged that students exposed to metacognitive instruction do well in problem solving process. Privileged metacognitive learners achieve higher level of achievement as compared to their counterparts who do not activate metacognitive processes during learning. On the other hand Sarwar et al. (2009), conducted a study to examine metacognition and achievement goals in relation to educational achievement at all levels but did not find any significant relationship between metacognition and academic achievement. Some earlier researchers also confirmed the same results. (Mousoulides \& Philippou, 2005 and Ergul, 2004). Keeping in view the diverse findings of these studies researcher tried to study metacognitive instruction and students' achievement in Pakistani background specifically in the domain of mathematics.

\section{Metacognition and Metacognitive Instruction}

Metacognition is the ability of a person to devise a plan, to complete an assignment by using previous information and knowledge, select a strategy to solve a given problem, monitor and evaluate the results, and change the strategy or plan if required for achieving the objective.

Primarily metacognition is concerned with the cognitive processes needed to solve problems which do not have authentic and mechanized procedures to solve (Schoenfeld, 1992). Some examples of Metacognitive activities are: devising a plan to solve an assignment, answering a given question using suitable skills and strategies, examining one's own understanding of a writing script or word problem, assessing or correcting one's self, evaluating the steps and procedures of a task, and becoming conscious of stimuli that may disrupt.

Different teaching techniques and strategies have been developed by educationists to boost metacognition in an appropriate way. Students can be trained to activate metacognitive processes and make out their proper use by instruction methods. Such methods are generally termed as metacognitive instruction (Teong, 2000; Mevarech \& Fridkin, 2006). Metacognitive instruction requires a real training of students to activate their metacognitive processes or control (Veenman et al., 2006). Metacognitive instructional strategy produces students that are able to grasp advanced cognitive processes, by allowing them to find out suitable problem solving strategy and use it under diverse conditions (Victor, 2004). Metacognitive instructional strategy makes students to be aware of their own knowledge, paraphrasing a problem, asking self 
addressed questions, linking between previous knowledge and new situation by considering the facts and monitoring the progression of learning. Students trained through metacognitive instruction develop their metacognitive skills and solve simple as well complex mathematical word problems easily and without any hesitation. They solve a complex mathematical word problem by segmenting it and then solving through asking a chain of self addressed questions for clarifying their thoughts and judgments (Teong, 2000). Researchers have used a number of metacognitive instruction strategies for teaching mathematics. Some of them are SOLVE, IMPROVE and CRIME ( Kramarski \& Mevarech, 1997; Teong, 2000). These methods use the hypothetical definition of metacognition, metacognitive knowledge and metacognitive skills and practicing of self addressed questions. Students are practiced to ask a series of self addressed questions while solving word problems about: understanding, connection, strategies, and reflection.

(a) Understanding Student articulates, and paraphrases the question's statement in his own words having focus on the content of mathematics and asking the questions. What is the problem? What does it require?

Student visualizes the problem by drawing a model, diagram or number line.

(b) Connection Student connects the given problem with the previous knowledge and asks.

Is the given mathematical word problem similar or different from mathematical operations I have done before? Asks explanation about similarity or difference?

(c) Strategies Student thinks about the suitable strategies to solve the mathematical word problem, and asks. Why should I prefer these strategies?

(d) Reflection Student reflects on solution, the procedure of solution and on himself as a word problem solver and asks. Can I solve this problem with another strategy? Does the answer of the problem have some reason or logic?

According to Kramarski \& Mevarech, (1997), activation of metacognitive processes during learning brings superior performance in different school subject including mathematics. Keeping in view the difficulties of students in solving mathematical word problems researcher decided to study the effect of independent variables; metacognitive 
instruction and traditional teaching method for teaching word problems solving on the sixth class students' learning achievements.

The present study's findings would not only be useful to students and teachers but also to other stake holders in education system like educational leaders, curriculum designers and policymakers. Students could use the same method to solve word problems; teachers could apply the same instructional strategy in their class rooms; educational leaders could facilitate the teachers and learners to implement Metacognitive instruction in mathematics classes to enhance the learning process in their institutions. The curriculum designers could include Metacognitive instruction in training courses of Mathematics teachers. In addition to this it would be an addition to the assets of research and knowledge.

\section{Objective of the Study}

The objective of the proposed research was to study the effect of metacognitive instruction on sixth class students' learning achievement in mathematical word problems through measuring their achievement with students who were taught through traditional method.

\section{Hypotheses of the Study}

Following hypotheses were translated from the objective of the study.

$\mathrm{H}_{01}$ : Sixth class students do not show a significant mean difference of pretest and posttest scores when exposed to metacognitive instruction.

$\mathrm{H}_{02}$ : Sixth class students do not show a significant mean difference of pretest and posttest scores when taught by traditional method.

$\mathrm{H}_{03}$ : There is no significant difference between achievement scores of students of sixth class who are taught by traditional method and those exposed to metacognitive instruction.

\section{Methodology}

Pretest-posttest control group design of true experimental research was used. Experimental study was carried out at a public school of district Abbottabad. Participants were allowed to study during ten experimental weeks under two different conditions from August to October 2014. 


\section{Participants}

The participants of the study consisted of all the 189 students of sixth classes in Govt. High School Abbottabad. 80 students were randomly selected as participants, then again randomly dividing those 80 students in two groups, experimental and control, each consisting of 40 students.

\section{Instructional Strategy}

An instructional strategy according to metacognitive instruction principles and procedures was developed. Strategy consisted of seven episodes, Study, Analyze, Visualize, Think about the possible strategy, Implement, Monitor and Evaluation. For each episode students used a series of self addressed questions for which they were trained, during the solving process of mathematical word problems. Each student was provided with an acronym card of all episodes of strategy (SAVTIME) along with questions with each episode for modeling and practicing during word problem solving process.

\section{Instrumentation}

An assessment test used as both pretest (to assess students before the experiment) and posttest (to assess students after the experiment) was used in the experiment for data collection. Test consisting of ten word problems was validated by experts and went through reliability accordingly. Word problems were selected by the same criteria as for those solved during study period.

1. The word problems had to be challenging and require metacognitive skills and behaviors.

2. The word problems would be a mixture of common word problems and genuine 'process' word problems.

3. All the word problems would be selected on the basis that prevents students from relying on regular procedures.

Marking rubric for word problems was also developed and validated by experts.

\section{Validation and Reliability}

A group of experts from the field of Mathematics were requested to refine the items of assessment test, marking rubric and instructional 
strategy for the purpose of validation. All the tools were modified and finalized in the light of experts' suggestions. The pilot study of Instructional strategy and assessment test was conducted before the experiment. In the beginning pilot students felt some problem but with the time they became used to it and acknowledged it as an effective strategy to solve word problems. The assessment test recorded a reliability coefficient of 0.783 by using Cronbach Alpha reliability analysis, after its revision.

In the present study researcher reduced the threats to internal validity and the effect of regression by randomly assigning the subjects in to control and experimental groups. Ten weeks time period was not long enough that cause Maturation as the threat. Random subject's selection, random assigning of subjects in to treatment and control groups, and providing a period of ten weeks between pretest and posttest, teachers of same qualification and teaching of same word problems to both groups were the measures used to prevent internal and external validity of experiment. The threat of mortality was also diminished by absence of dropout case in present study also.

\section{Procedure of Study}

The study was true experimental specifically Pretest-Posttest Control Group Design was used. The steps used in the study were:

- Random assignment of subjects into control and experimental group.

- Conduction of Pretest

- Treatment of control group through traditional method and experimental group through metacognitive instruction

- Conduction of posttest

Experimental group was exposed to metacognitive instruction strategy provided with direct explanation and practice in 7 step instruction, while solving word problems. Each student was given an acronym card of the strategy, and each stage of 7 step strategy used in word problem solving was read and explained. Then the teacher modeled the process of applying these stages during word problem solving. During the study, all students worked together with their seat fellows under the supervision of teacher and would gradually take over the full responsibility of solving mathematical word problems by themselves. A chart of different stages of strategy and related question, similar to acronym card was hanged in the class room. The acronym card provided 
to each student prompts in the form of checklists, helped students to work systematically and strategically during the process of word problem solving. Students got challenged to obtain information to solve word problem with the practice of self-questioning. On the other hand control group was taught by traditional teaching method that is Chalk and Board method where teacher solved the question on board and students copied it on their notebooks. Students neither tried to understand and analyzed the statement of the problem nor used the prior knowledge. There was hardly any effort to improve student's thinking process. Both groups studied same word problems for one period daily throughout the same period of experiment that consisted of ten instructional weeks. All the participants in treatment and control groups took the pretest at the start and posttest at the end of the ten instructional weeks.

\section{Analysis of Data}

The data were collected and analyzed through applying descriptive statistics and t-test. The best technique to compare the mean score of two groups is t-test (Gay, 1996). Researcher used t-statistics on pretest scores to get the initial difference between the scores and to confirm the assumption of equality of control and experimental groups.

Following results were found and given in the following table:

Table 1

Equivalence of Experimental and Control Group on the Scores of Pretest

\begin{tabular}{lllllllll}
\hline $\begin{array}{l}\text { Instructional } \\
\text { Groups }\end{array}$ & $\mathrm{N}$ & Mean & MD & SD & $\begin{array}{l}\text { Std. } \\
\text { Error }\end{array}$ & df & t-value & Sig. \\
\hline $\begin{array}{l}\text { Experimental } \\
\text { Control }\end{array}$ & 40 & 42.25 & 0.55 & 19.41 & 3.06 & & & \\
\hline *The mean difference is not significant at the .05 level & & & & & & & \\
\hline
\end{tabular}

Results in table 1 above show that the mean difference $(\mathrm{MD}=0.55)$ of both groups was slightly different. The t- statistics t $(78)=0.133, p=$ .89, $\alpha=.05$ provided evidence that there was no difference between experimental and control groups and both before the start of the experiment. Both groups were equivalent.

The following table presents the comparison of experimental group mean scores in pretest and posttest. 
Table 2

Comparison of Mean Scores of Experimental Group in Pretest and Posttest

\begin{tabular}{lllllllll}
\hline $\begin{array}{l}\text { Instructional } \\
\text { Groups }\end{array}$ & $\mathrm{N}$ & Mean & MD & SD & $\begin{array}{l}\text { Std. } \\
\text { Error }\end{array}$ & df & t-value & Sig. \\
\hline $\begin{array}{l}\text { Pretest } \\
\text { Posttest }\end{array}$ & 40 & 42.25 & -12.62 & 19.415 & 3.069 & & & \\
\hline *The mean difference is significant at the .05 level & & 19.024 & 3.007 & 78 & -2.936 & $0.004^{*}$ \\
\hline
\end{tabular}

Results in table 2 above show that the mean score of posttest (54.87) is significantly higher than the mean score of pretest (42.25) for experimental group. The t- statistics $t$ (78) $=-12.62, p=.004, \alpha=.05$ confirms a statistically significant difference between the mean scores. These results proved that experimental group showed a noteworthy improvement implying that null hypothesis "Sixth class students do not show a significant mean difference of pretest and posttest scores when exposed to metacognitive instruction" was rejected and an alternate hypothesis " Sixth class students show a significant mean difference of pretest and posttest scores when exposed to metacognitive instruction"' was accepted.

This proved Metacognitive instruction as an effective method for teaching mathematical word problems at elementary level.

Now it is interesting to reflect on any improvement in the scores of control group. The following table presents the comparison of control group mean scores in pretest and posttest.

Table 3

Comparison of Mean Scores of Control Group in Pretest and Posttest

\begin{tabular}{lllllllll}
\hline $\begin{array}{l}\text { Instructional } \\
\text { Groups }\end{array}$ & $\mathrm{N}$ & Mean & MD & SD & $\begin{array}{l}\text { Std. } \\
\text { Error }\end{array}$ & df & t-value & Sig. \\
\hline Pretest & 40 & 41.70 & - & 17.343 & 2.741 & & & \\
Posttest & 40 & 46.307 & 4.607 & 16.794 & 2.655 & 78 & -1.206 & 0.2311 \\
\hline *The mean difference is not significant at the .05 level & & & & & \\
\hline
\end{tabular}

The results given in table 3 show that the mean score of posttest (46.307) is higher than the mean score of pretest of control group (41.70) with a mean difference $(\mathrm{MD}=4.607)$. The $\mathrm{t}$ - statistics $\mathrm{t}(78)=-1.206, p$ $=.2311, \alpha=.05$ provides evidence that control group students have also shown some improvement after teaching by traditional method. Although there is a difference but it is not significant. These results indicate to accept the null hypothesis "Sixth class students do not show a significant 
mean difference of pretest and posttest scores when taught by traditional method."' The results of descriptive statistics in table 2 and table 3 reveal that both groups have shown an improvement during the treatment period. But the question arises that which group has shown more improvement and progress and which method is more appropriate for solving mathematical word problems. To obtain the answer comparison of mean scores in posttest of both groups is presented in the following table.

Table 4

Comparison of Experimental and Control Group on the Scores of Posttest

\begin{tabular}{lllllllll}
\hline $\begin{array}{l}\text { Instructional } \\
\text { Groups }\end{array}$ & $\mathrm{N}$ & Mean & MD & SD & $\begin{array}{l}\text { Std. } \\
\text { Error }\end{array}$ & df & t-value & Sig. \\
\hline $\begin{array}{l}\text { Experimental } \\
\text { Control }\end{array}$ & 40 & 54.87 & & 19.024 & 3.007 & & & \\
& 40 & 46.30 & 8.57 & 16.794 & 2.655 & 78 & 2.134 & $0.360^{*}$ \\
\hline *The mean difference is significant at the .05 level & & & & & \\
\hline
\end{tabular}

The posttest results in table 4 above show that the posttest mean scores of experimental group (54.87) is higher than the posttest mean score of control group (46.30). The t- statistics t (78) $=2.134, p=.0360$, $\alpha=.05$ also shows a significant difference between the two means. Similarly the mean difference of both groups in pretest and posttest from Table 2 and Table $3(12.62-4.607=8.013)$ indicates a higher difference in the achievement scores of experimental and control group in posttest. These results show enough evidence to reject the null hypothesis "There is no significant difference between achievement scores of students of sixth class who are taught by traditional method and those exposed to metacognitive instruction"' and accept the alternate hypothesis "There is significant difference between achievement scores of students of sixth class who are taught by traditional method and those exposed to metacognitive instruction.",

There is a major variation between achievement scores of students of sixth class taught by traditional method and exposed to metacognitive instruction. This was an indicator for the effectiveness of metacognitive instruction as the experimental group performed well as compared to control group. 


\section{Findings}

The findings of the study indicated that:

i. Sixth class students when exposed to metacognitive instruction achieve a significantly higher mean score in post test than in pretest.

ii. There is no major difference between the pretest and posttest mean scores of sixth class students taught by traditional method.

iii. Sixth class students exposed to metacognitive instruction achieve significantly higher scores than those who are taught by traditional method.

There is an indication of a significant difference between the achievement scores of students of sixth class taught by two different methods: Metacognitive instruction and Traditional method. Experimental group showed better performance in word problem solving as compared to control group.

\section{Discussion and Recommendations}

The present study has revealed a positive relationship between metacognitive instruction and students' achievement in mathematical word problems. Previous research has also proved that students who stimulate metacognitive processes easily analyze the requirements of a problem or learning situation and think about possible and appropriate strategies for that specific situation. Schraw et al., (2006), also established the same results. The findings of the study also proved that students exposed to metacognitive instruction develop their metacognitive skills and solve mathematical word problems with satisfaction. Mevarech \& Fridkin (2006) and Veenman et al, (2006) also showed the same results. On the other hand some researcher found no relationship between metacognition and academic achievement (Mousoulides \& Philippou, 2005; Sarwar et al., 2009). The reason for this difference in result may be because the studies that found no significant relationship between metacognition and academic achievement were conducted in under developed countries while other were conducted in developed countries. But the result of present study proved that metacognitive instruction may produce positive result in Pakistani background that is not included in developed countries.

Students taught by traditional method of teaching also performed well in their posttest as compared to pretest. This finding proves that 
traditional method which is usually used in classrooms also shows some improvement in students' achievement.

But when we compare the metacognitive instruction with traditional method the students of experimental group performance is extraordinary than their counterparts. Kramarski \& Mevarech (2003), also confirmed the same results. The findings of the present study conducted in Pakistani background proved, Metacognitive instruction as a better strategy for teaching mathematical word problems solving and lead the researcher to recommend:

This technique may be used for teaching mathematical word problems at elementary and secondary levels.

Educational leaders and policy makers may organize and make possible the implementation of Metacognitive instructions. Curriculum planners may include Metacognitive instruction for teaching mathematical word problems as an important component of pre service and in service training courses of mathematics teachers. 


\section{References}

Ergul, H. Dr. (2004). Relationship between student characteristics and academic achievement in distance education and application on students of Anadolu University. Turkish Online Journal of Distance Education, 5 (2).

Gay, L. R. (1992). Educational Research: Competencies for Analysis and Application. Publisher Merrill, The University of Michigan.

Helms-Lorenz, M., \& Jacobse, A.E. (2008). Metacognitive skills of the gifted from a cross-cultural perspective. In F. Shaughnessy, M.V.J. Veenman, \& C. Kleyn- Kennedy (Eds.), Meta-cognition: A recent review of research, theory, and perspectives (pp. 3-43). Hauppage, NY:Nova Science. Inspectie van het.

Kramarski, B \& Mevarech, Z (1997) Cognitive-metacognitive training within a problem solving based Logo environment. British Journal of Educational Psychology, 67(4), p. 425-446.

Kramarski, B., \&Mevarech, Z. R. (2003). Enhancing mathematical reasoning in the classroom: The effects of cooperative learning and metacognitive training. American Educational, Research Journal, 40, 281-310.

Maqsud, M. (1997). Effects of Metacognitive Skills and Nonverbal Ability on Academic Achievement of High School Pupils. Educational Psychology, 17(4), p. 387-397.

Mevarech, Z. R., \& Fridkin, S. (2006). The effects of IMPROVE on mathematical knowledge, mathematical reasoning and meta- cognition. Metacognition and Learning Journal, 1, 85-97.

Mousoulides, N., \& Philippou, G. (2005). Students' motivational beliefs, selfregulation strategies and mathematics achievement. In $\mathrm{H}$. L. Chick, \& J. L. Vincent(Eds.), Retrieved December 7, 2014, from http://www.emis.de/proceedings/

Rahman, F., Jumani, N. B., Chaudry, M. A., Chisti, S. H., \& Abbasi, F. (2010). Impact of Metacognitive Awareness on Performance of Students in Chemistry. Contemporary Issues in Education Research, 3(10), p. 39-44.

Salma, J. \& Sherwin, R. (2012). Students' difficulties in comprehending mathematical word problems in English language learning contexts. International Researcher, 1(3). 
Sarwar, M., Yousaf, M. I.,Hussain, S., \& Noreen, S. (2009). Relationship Between Achievement Goals, Meta-Cognition And Academic Success in Pakistan. Journal of College Teaching \& Learning, 6(5), 19-30.

Schoenfeld, A. (1992). Learning to Think Mathematically: Problem Solving, Metacognition and Sense making in Mathematics. Handbook of research on mathematics thinking and learning. (Editor: Grouws, D) New York: MacMillan, p. 334-370.

Teong, S. K. (2000). The effect of Metacognitive Training on Mathematical Word Problem Solving of Singapore 11-12 year olds In a computer environment. Unpublished Doctoral Thesis. School of Education: University of Leeds.

Veenman, M. V. J., Van Hout-wolters, B., \& Afflerbach, P. (2006). Metacognitive and learning: Conceptual and methodological considerations. Meta-cognition Learning, 1, 3-14.

Victor, A.M. (2004). The effects of metacognitive instruction on the planning and academic achievement of first and second grade children. Unpublished Doctoral Thesis. Chicago, IL: Graduate College of the Illinois. Institute of Technology.

Xin Y. P. (2007). Word problem solving tasks in textbooks and their relation to student performance. The Journal of Educational Research, 100, 347-360.

Received on: August 28, 2016

Revised on: December 15, 2016

Accepted on: December 28, 2016 